International Journal of Advances in Chemistry (IJAC) Vol. 4, No.1, February 2018

\title{
REMOVAL OF TOXIC CHEMICALS AND BIOLOGICAL POLLUTANTS FROM GROUNDWATER WELLS USING MODIFIED DOWNFLOW HANGING SPONGE REACTOR
}

\author{
Abdou Saad El-Tabl and Mahmoud Sayed Ahmed Shahin \\ Chemistry Department, Faculty of Science, Menoufia University, Egypt
}

\begin{abstract}
Water pollution is one of the most important environmental problems in the world. In developing countries, contaminated water has frequently caused water diseases. Today, water borne toxic chemicals (anions and heavy metal ions) and biological pollutants pose a great threat to the safety of water supplies. Currently, the quality of groundwater with respect to pollutants is of great concern. Modified Downflow Hanging Sponge (DHS) reactor will be a good groundwater treatment technology in the near future, it is used for excellent removal of heavy metals, anions, organic pollutants and harmful microbes, and also the reactor has advantages like low cost, easy to apply and satisfaction level. In order to achieve these objectives, treatment scheme has been investigated. It consists of mixing organic chelator with impure groundwater in different concentrations followed by a downflow hanging sponge (DHS) reactor. In the presence of $0.5 \mathrm{~g} / \mathrm{L}$ of the chelator, the average removal of total $\mathrm{NO}_{3}$ and $\mathrm{NO}_{2}$ and (total dissolved solids) TDS are respectively $72 \%, 62 \%$ and $75 \%$. The results show that, when Cd treated with chelator, the amount decreases from 0.0063 to $0.0 \mathrm{mgL}^{-1}$ (100\%) after $1 \mathrm{~h}$, Cu decreases from 0.0023 to $0.0 \mathrm{mgL}^{-1}$ (100\%) after $1 \mathrm{~h}$, Fe decreases from 0.4 to $0.0 \mathrm{mgL}^{-1}$ (100\%) after $1 \mathrm{~h}$, Mn decreases from 0.3 to $0.0 \mathrm{mgL}^{-1}$ (100\%) after $1 \mathrm{~h}$ and $\mathrm{Zn}$ decreases from 0.012 to $0.0 \mathrm{mgL}^{-1}(100 \%)$ after $1 \mathrm{~h}$. Also, the results show removal of fecal coliform . Decreased from 50 to 0 and the overall removal efficiency of fecal coliform is (100\%).
\end{abstract}

\section{KEYWORDS}

DHS reactor, Chelator, Toxic Chemicals, Fecal Coliforms.

\section{INTRODUCTION}

One-third of the world's population suffers from water deficiency[1].The primitive individual water supplies are mostly present in unfortunate rural communities that depend on raw ground water, maximizing the population exposure to water pathogens. In addition, the situation in rural towns includes wild and domestic animals, intensive grazing, agriculture activities and dispersed excreta from both humans and animals, which characterized the major dim resources associated with groundwater pathogens[2].Therefore, water pollution has become a serious issue in the present situation, affecting all living creatures, household, recreation, fishing, transportation, and other commercial activities[3]. Thousands of organic, inorganic, and biological pollutants have been reported as water contaminants [3-5]. Some of them have severe side effects and toxicities with a few being lethal and carcinogenic [6-8]. According to the World Health Organization 
International Journal of Advances in Chemistry (IJAC) Vol. 4, No.1, February 2018

(WHO) an average of 50,000 people die each day from diseases associated with contaminated water[9]. Drinking water used is either groundwater sources or surface water sources (such as rivers, lakes, and streams). Nearly one-fifth of all water used in the world at present is obtained from groundwater[10]. Groundwater is considered superior in quality relative to surface water with respect to bacteriological content, turbidity, and total organic concentrations. While with respect to mineral content (hardness, iron, manganese), groundwater may be inferior and require additional treatment[11]. Metal ions such as cadmium, chromium, mercury, selenium and lead, etc. have serious toxicities. At higher concentration than permissible limit [12-15]. Cobalt causes vomiting, nausea, asthma, and carcinoma. Besides, cobalt is also responsible for thyroid, gastrointestinal, and liver problems [16-18]. Zinc is required for the growth of human beings, but high concentrations more than the permissible limit $[3.0 \mathrm{mg} / \mathrm{L}]$ cause poor growth and mental fever[19-21]. Besides, nitrate, sulfate, phosphate, fluoride, chloride, and oxalate have also some hazardous effects. For example, high concentration of nitrate results into blue babies disease (methemoglobinemia) in children[22]. On the other hand, it is well-known that, fluorosis is due to high levels of fluoride in water[23]. It has been reported that, high concentrations of other anions such as sulfate, phosphate, chloride, oxalate, etc. change water taste[24]. Many organic pollutants have been found in different water resources. These belong to various types such as pesticides, fertilizers, hydrocarbons, phenols, plasticizers, biphenyls, detergents, oils, greases, pharmaceuticals, etc [25].The side effects and toxicities of these contaminants were reported[2527]. The different types of microbes present in wastewater may be responsible for various diseases. The injurious microorganisms either in soluble, colloidal, or in suspended form are virus, bacteria, fungi, algae, amoebas, and planktons. These microbes are responsible for causing several illnesses called waterborne diseases[28, 29]. Because of these sorts of pollution, the surface and groundwater at some places of the world are contaminated and not fit for drinking purposes. By 2020, the global population is expected to reach up to 7.9 billion[30]. And because of this the world may be under great water scarcity. Therefore, the removal of these pollutants from contaminated water is an urgent need for providing disease-free health to our society. The DHS post treatment system is designed for application in developing countries as it yields positive energy balance. The principle of this system is the use of polyurethane sponge as a medium to retain biomass. The concept is somewhat similar to that of trickling filter, except that the packing material was sponge, which has avoided space of more than $90 \%$, resulting in a significant increase in entrapped biomass and thus longer reverses osmosis (RO). As the sponge in DHS is not submerged and freely hung/placed in the air, oxygen gets dissolved into the ground water as it flows down and therefore there is no need of aeration or any other energy input to the system. Moreover, production of excess sludge from DHS was negligible as longer RO provides ample time for autolysis of sludge in the system itself. Ground water is trickled from the top of the reactor and purified by microorganisms retained both inside and outside of the sponge media as the Ground water flows vertically down through the reactor. Moreover, excess sludge production from DHS was negligible thus eliminating secondary sludge that was troublesome to dispose of. A pilot-scale DHS $\left(0.38 \mathrm{~m}^{3}\right.$; volume of sponge) treating wells ground water was investigated.

\section{MATERIALS AND METHODS}

\subsection{Downflow Hanging Sponge (DHS) system}

The DHS unit column as shown below consists of four equal segments connected vertically, each segment will be equipped with $25 \mathrm{~L}$ of polyurethane foam (PF) warped with plastic material 
randomly distributed in the whole reactor. The DHS system will be made of PVC, with a capacity of $0.3 \mathrm{~m}^{3}$ and has an internal diameter of $0.16 \mathrm{~m}$. The height of the reactor is $0.88 \mathrm{~m}$. The reactor will be packed with $\mathrm{PF}$ which represents $34 \%$ of the total liquid reactor volume. The characteristics of the PF (sponge) are surface area $256 \mathrm{~m}^{2} / \mathrm{m}^{3}$, density $30 \mathrm{~kg} / \mathrm{m}^{3}$, void ratio 0.9 , and pore size of $0.63 \mathrm{~mm}$. The total volume of the PF will be $100 \mathrm{~L}$. The size of the used sponge PF (cylindrical shape) will be $27 \mathrm{~mm}$ height $\times 4 \mathrm{~mm}$ diameter. The wastewater effluent will be flowed by gravity to the distributor which will be located on the top of the DHS module and will be rotated at $15 \mathrm{rpm}$. Chemical parameters such as chemical oxygen demand (COD), Biological oxygen demand (BOD), Total suspended solids (TSS), TDS, $\mathrm{NO}_{2}$ and $\mathrm{NO}_{3}$ will be monitored at retention time $6 \mathrm{~h}$ and $3 \mathrm{~h}$ according to American Public Health Association (APHA) (2005) "Standard Methods for the Examination of Water and Wastewater".

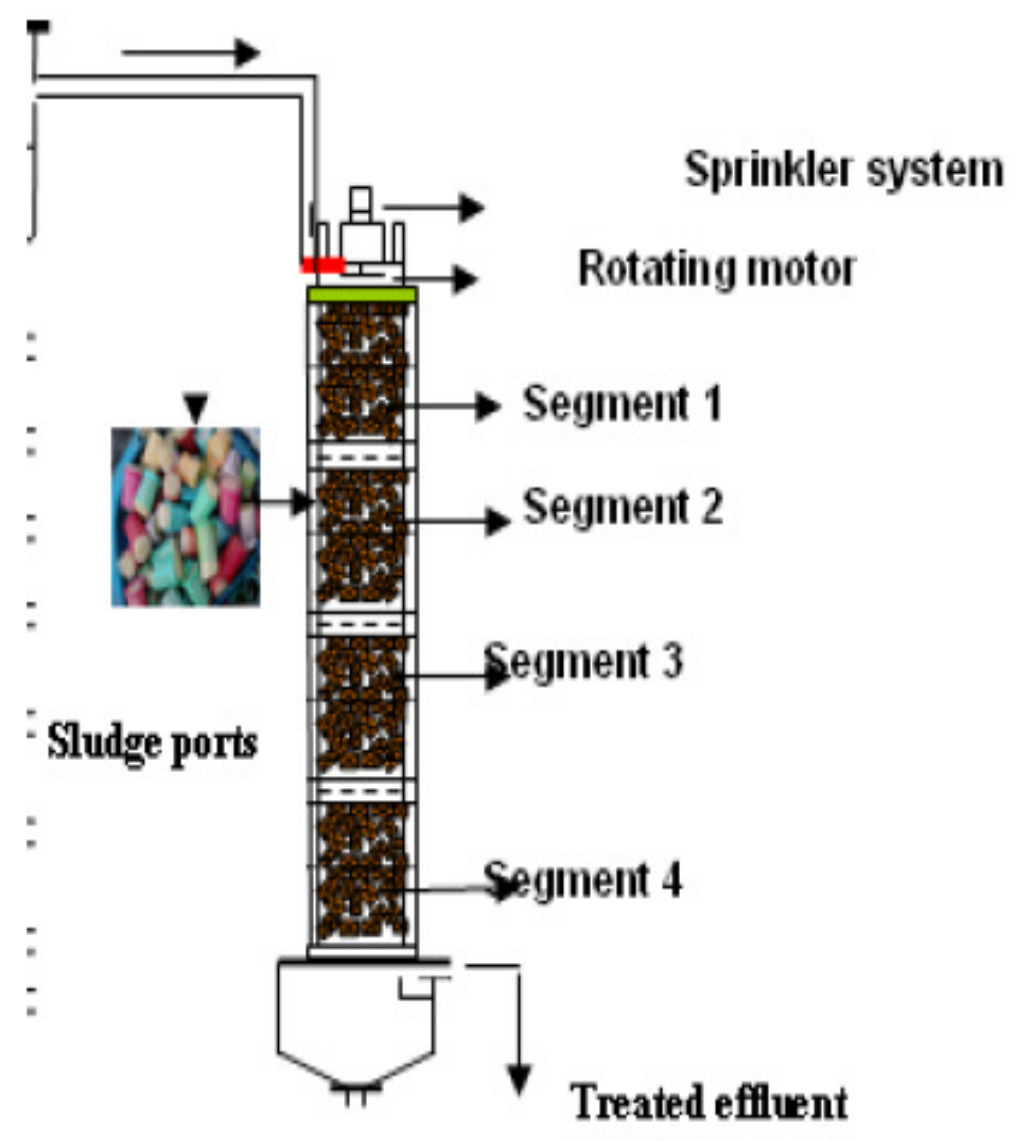

\subsection{Synthesis of the organic chelator}

Tartaric acid $(10.0 \mathrm{~g}, 0.067 \mathrm{~mol})$ was heated $\left(70-80 \mathrm{C}^{\mathrm{o}}\right)$ in $50 \mathrm{ml}$ methanol for $1 \mathrm{~h}$.Five drops of conc. $\mathrm{H}_{2} \mathrm{SO}_{4}$ were added, and continuous refluxed with stirring for $3 \mathrm{~h}$. Hydrazine (14.0 g, 0.078 mol) was added drop by drop. The mixture was refluxed with stirring for $2 \mathrm{~h}$ and the brown precipitate formed was separated, washed with methanol and dried in air. The structure of the chelator and suggested structure of removal ions and 3D are shown in charts (1) and (2). 
International Journal of Advances in Chemistry (IJAC) Vol. 4, No.1, February 2018
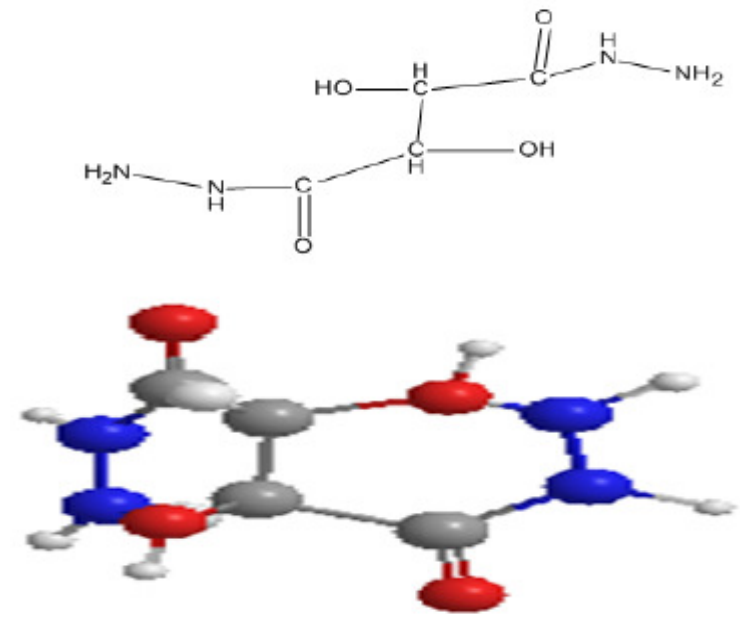

Chart (1): Structure of the chelator and 3D.
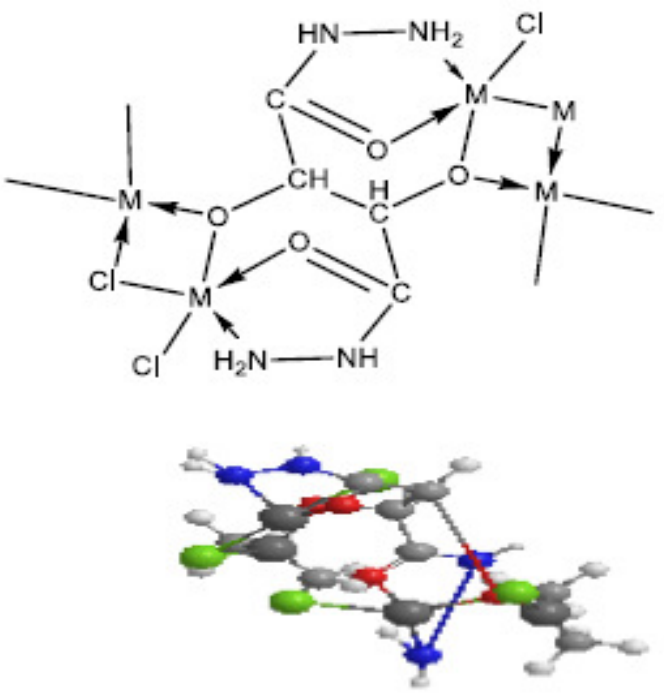

Chart (2): Suggested structure of removal ions and 3D.

\subsection{Measurement of chelator capacity in the laboratory}

In order to study the chelator capacity in the laboratory, Different ratios of metal salts which are present in wastewater with the chelator are studied with different ratio (1Ch:1M, 1Ch:2M, 1Ch:3M, 1Ch:5M, 4Ch:1M) (ch= chelator, M=metal salt). Biosorption capacity (qe) can be calculated in $\mathrm{mg} / \mathrm{g}$ as follows:

$$
\mathbf{Q}_{\mathrm{e}}=\left(\mathbf{C}_{\mathbf{o}}-\mathbf{C}_{\mathrm{e}}\right) \mathrm{V} / \mathbf{m}
$$

Percentage of metal removal can also be displayed by the percentage of metal removal as follows:

Metal removal $(\%)=100\left(C_{0}-C_{e}\right) / C o$

$\mathrm{M}=\mathrm{Cu}(\mathrm{II}), \mathrm{Co}(\mathrm{II}), \mathrm{Ni}(\mathrm{II}), \mathrm{Fe}(\mathrm{II}), \mathrm{Cd}(\mathrm{II}), \mathrm{Zn}(\mathrm{II}), \mathrm{Pb}(\mathrm{II})$. Anions = Cl, $\mathrm{SO}_{4},(\mathrm{OAc})$ or $\mathrm{NO}_{3}$. 


\section{RESULTS AND DISCUSSION}

When the chelator is treated with the metal ions in $(1 \mathrm{ch}: 1 \mathrm{M})$ molar ratio, it is found that the removal efficiency after $30 \mathrm{~min}\left(70^{\circ} \mathrm{C}\right)$ of $\mathrm{Mn}$ is $43.56 \%, \mathrm{Fe}$ is $29.18 \%, \mathrm{Cd}$ is $35.03 \%, \mathrm{Cu}$ is $30.26 \%, \mathrm{~Pb}$ is $41.62 \%$ and $\mathrm{Ni}$ is $33.42 \%$, after $60 \mathrm{~min}\left(70^{\circ} \mathrm{C}\right)$ removal of $\mathrm{Mn}$ is $43.54 \%, \mathrm{Fe}$ is $48.40 \%, \mathrm{Cd}$ is $57.26 \%, \mathrm{Cu}$ is $57.94 \%, \mathrm{~Pb}$ is $60.98 \%$ and $\mathrm{Ni}$ is $44.28 \%$, after $90 \min \left(70^{\circ} \mathrm{C}\right)$ of $\mathrm{Mn}$ is $47.83 \%, \mathrm{Fe}$ is $49.20 \%, \mathrm{Cd}$ is $57.91 \%, \mathrm{Cu}$ is $58.34 \%, \mathrm{~Pb}$ is $63.18 \%$ and $\mathrm{Ni}$ is $47.83 \%$, and finally after $120 \mathrm{~min}\left(70^{\circ} \mathrm{C}\right)$ removal of $\mathrm{Mn}$ is $59.36 \%$, Fe is $50.01 \%, \mathrm{Cd}$ is $60.19 \%, \mathrm{Cu}$ is $59.54 \%, \mathrm{~Pb}$ is $64.19 \%$ and $\mathrm{Ni}$ is $48.83 \%$. The concentrations of ions against time were represented in figure 1 .

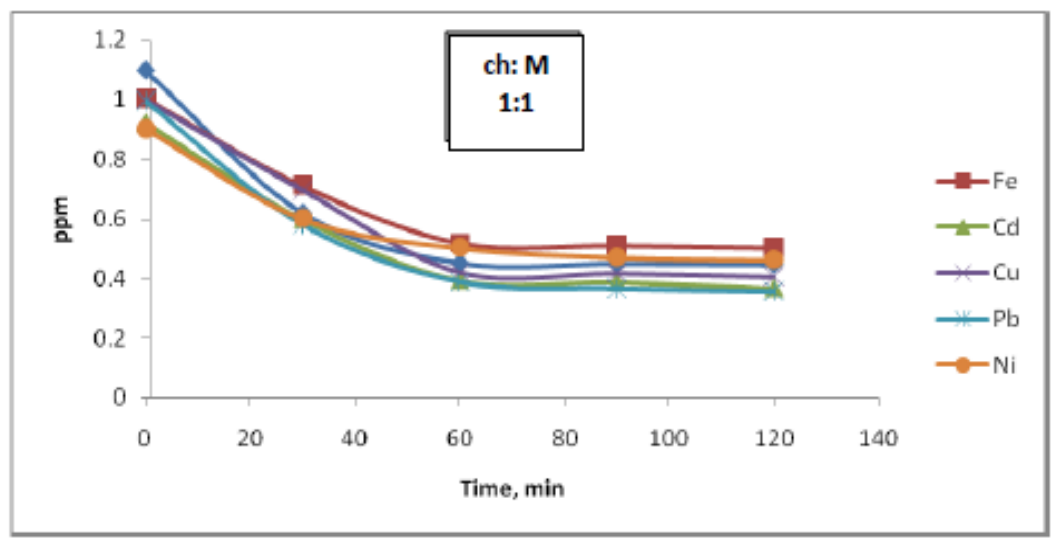

Fig.1:- Variation concentration of heavy metals at molar ratio (1ch:1M) against time

When the chelator is treated with the metal ions in $(1 \mathrm{ch}: 2 \mathrm{M})$ molar ratio, we found that the removal efficiency after $30 \mathrm{~min}\left(70^{\circ} \mathrm{C}\right)$ of $\mathrm{Mn}$ is $10 \%, \mathrm{Fe}$ is $15.18 \%, \mathrm{Cd}$ is $16.74 \%, \mathrm{Cu}$ is $18.94 \%$, $\mathrm{Pb}$ is $15.84 \%$ and $\mathrm{Ni}$ is $15.14 \%$, after $60 \mathrm{~min}\left(70^{\circ} \mathrm{C}\right)$ of $\mathrm{Mn}$ is $21.16 \%, \mathrm{Fe}$ is $24.03 \%, \mathrm{Cd}$ is $27.03 \%, \mathrm{Cu}$ is $24.42 \%, \mathrm{~Pb}$ is $26.63 \%$ and $\mathrm{Ni}$ is $28.98 \%$, after $90 \mathrm{~min}\left(70^{\circ} \mathrm{C}\right)$ of $\mathrm{Mn}$ is $21.32 \%, \mathrm{Fe}$ is $23.97 \%, \mathrm{Cd}$ is $28.22 \%, \mathrm{Cu}$ is $26.08 \%, \mathrm{~Pb}$ is $26.94 \%$ and $\mathrm{Ni}$ is $29.18 \%, 120 \mathrm{~min}\left(70^{\circ} \mathrm{C}\right)$ of $\mathrm{Mn}$ is $21.63 \%, \mathrm{Fe}$ is $24.45 \%, \mathrm{Cd}$ is $28.69 \%, \mathrm{Cu}$ is $26.48 \%, \mathrm{~Pb}$ is $28.05 \%$ and $\mathrm{Ni}$ is $29.78 \%$. The concentrations of ions against time were represented in figure 2.

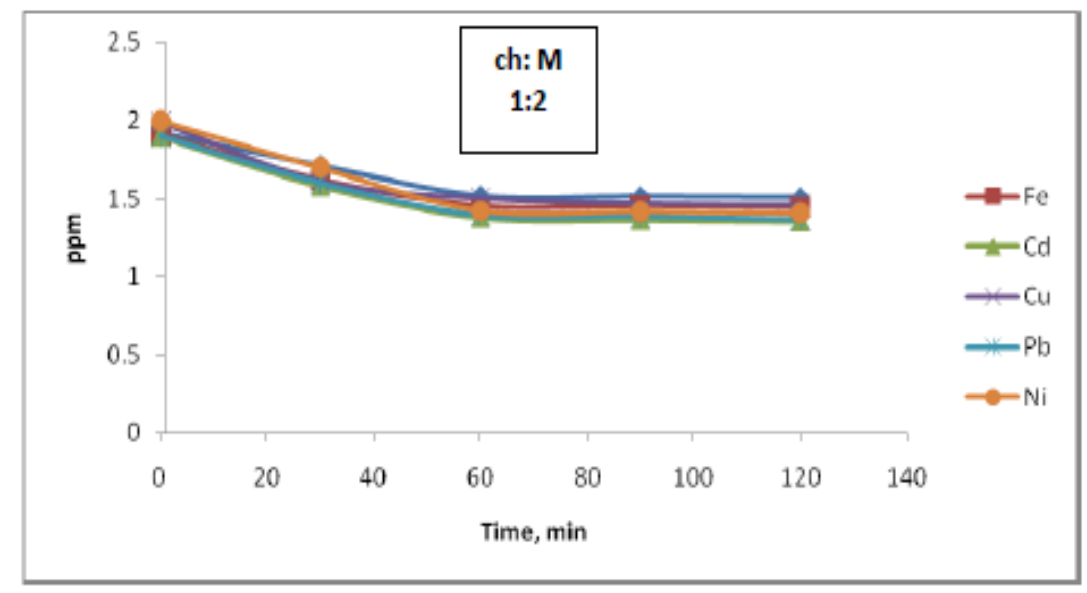

Figure .2:- Variation concentration of heavy metals at molar ratio (1ch:2M) against time 
International Journal of Advances in Chemistry (IJAC) Vol. 4, No.1, February 2018

When the chelator is treated with the metal ions in $(1 \mathrm{ch}: 3 \mathrm{M})$ molar ratio, it is found that the removal efficiency after $30 \mathrm{~min}\left(70^{\circ} \mathrm{C}\right)$ of $\mathrm{Mn}$ is $6.96 \%, \mathrm{Fe}$ is $14.47 \%, \mathrm{Cd}$ is $10.34 \%, \mathrm{Cu}$ is $12.69 \%, \mathrm{~Pb}$ is $12.87 \%$ and $\mathrm{Ni}$ is $13.08 \%$, after $60 \mathrm{~min}\left(70^{\circ} \mathrm{C}\right)$ removal of $\mathrm{Mn}$ is $16.51 \%, \mathrm{Fe}$ is $20.86 \%, \mathrm{Cd}$ is $13.79 \%, \mathrm{Cu}$ is $18.62 \%, \mathrm{~Pb}$ is $18.80 \%$ and $\mathrm{Ni}$ is $20.21 \%$, after $90 \mathrm{~min}\left(70^{\circ} \mathrm{C}\right)$ removal of $\mathrm{Mn}$ is $16.65 \%, \mathrm{Fe}$ is $21.59 \%, \mathrm{Cd}$ is $15.17 \%, \mathrm{Cu}$ is $18.69 \%, \mathrm{~Pb}$ is $19.06 \%$ and $\mathrm{Ni}$ is $20.31 \%$, finally after $120 \mathrm{~min}\left(70^{\circ} \mathrm{C}\right)$ of $\mathrm{Mn}$ is $17.06 \%, \mathrm{Fe}$ is $21.92 \%, \mathrm{Cd}$ is $15.48 \%, \mathrm{Cu}$ is $18.79 \%, \mathrm{~Pb}$ is $19.70 \%$ and $\mathrm{Ni}$ is $20.95 \%$. The concentrations of ions against time were represented in figure 3 .

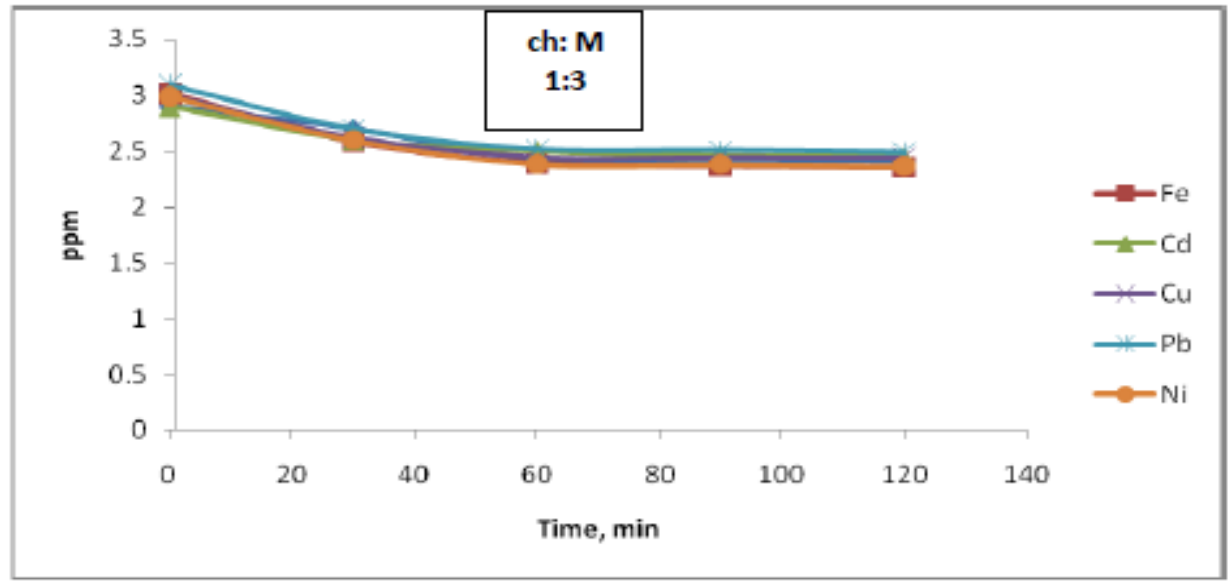

Figure.3:- Variation concentration of heavy metals at molar ratio (1ch:3M) against time

When the chelator is treated with the metal ions in $(1 \mathrm{ch}: 5 \mathrm{M})$ molar ratio, it is found that the removal efficiency after $30 \mathrm{~min}\left(70^{\circ} \mathrm{C}\right)$ of $\mathrm{Mn}$ is $7.74 \%, \mathrm{Fe}$ is $8.30 \%, \mathrm{Cd}$ is $4.69 \%, \mathrm{Cu}$ is $7.89 \%$, $\mathrm{Pb}$ is $5.61 \%$ and $\mathrm{Ni}$ is $7.59 \%$, after $60 \mathrm{~min}\left(70^{\circ} \mathrm{C}\right)$ removal of $\mathrm{Mn}$ is $9.70 \%, \mathrm{Fe}$ is $12.36 \%, \mathrm{Cd}$ is $13.31 \%, \mathrm{Cu}$ is $11.99 \%, \mathrm{~Pb}$ is $9.47 \%$ and $\mathrm{Ni}$ is $10.97 \%$, after 90 min $\left(70^{\circ} \mathrm{C}\right)$ removal of $\mathrm{Mn}$ is $10.74 \%, \mathrm{Fe}$ is $12.80 \%, \mathrm{Cd}$ is $13.39 \%, \mathrm{Cu}$ is $12.11 \%, \mathrm{~Pb}$ is $9.63 \%$ and $\mathrm{Ni}$ is $11 \%$, finally after 120 $\min \left(70^{\circ} \mathrm{C}\right)$ of $\mathrm{Mn}$ is $10.92 \%, \mathrm{Fe}$ is $13 \%, \mathrm{Cd}$ is $13.62 \%, \mathrm{Cu}$ is $12.53 \%, \mathrm{~Pb}$ is $9.79 \%$ and $\mathrm{Ni}$ is $11.01 \%$. The concentrations of ions against time were represented in figure 4 .

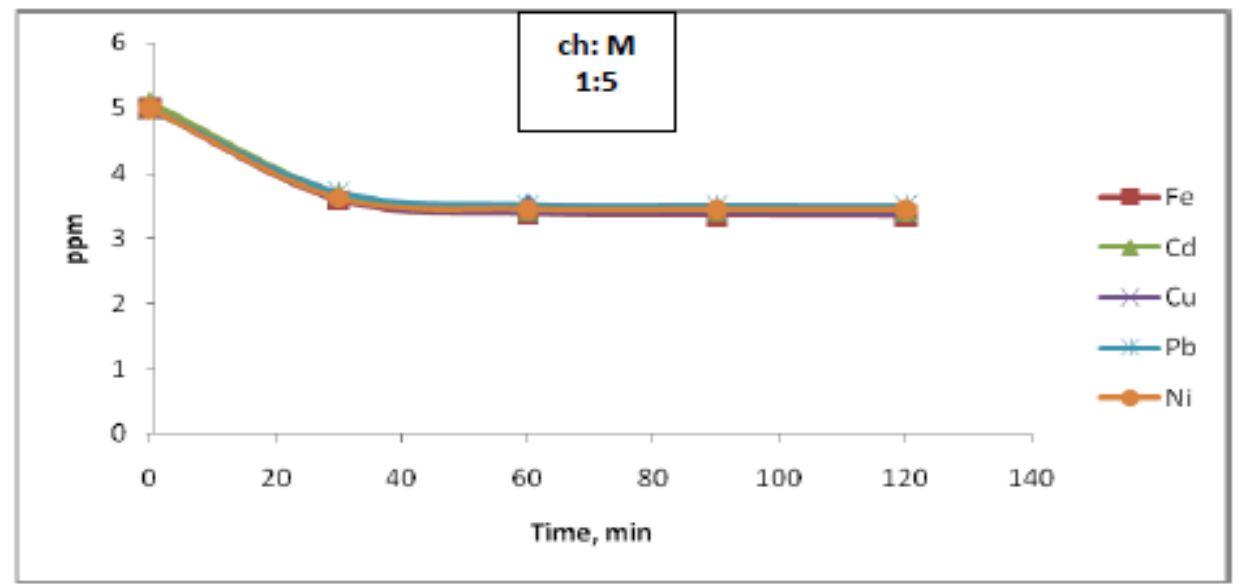

Figure 4:- Variation concentration of heavy metals at molar ratio (1ch:5M) against time 
International Journal of Advances in Chemistry (IJAC) Vol. 4, No.1, February 2018

When the chelator is treated with the metal ions in $(4 \mathrm{ch}: 1 \mathrm{M})$ molar ratio, it is found that the removal efficiency after $30 \mathrm{~min}\left(70^{\circ} \mathrm{C}\right)$ of $\mathrm{Mn}$ is $47 \%, \mathrm{Fe}$ is $31.37 \%, \mathrm{Cd}$ is $36.33 \%, \mathrm{Cu}$ is $32.26 \%$, $\mathrm{Pb}$ is $40.92 \%$ and $\mathrm{Ni}$ is $32.85 \%$, after $60 \mathrm{~min}\left(70^{\circ} \mathrm{C}\right)$ removal of $\mathrm{Mn}$ is $100 \%$, $\mathrm{Fe}$ is $100 \%, \mathrm{Cd}$ is $100 \%, \mathrm{Cu}$ is $100 \%, \mathrm{~Pb}$ is $100 \%$ and $\mathrm{Ni}$ is $100 \%$. The concentrations of ions against time were represented in figure 5 .

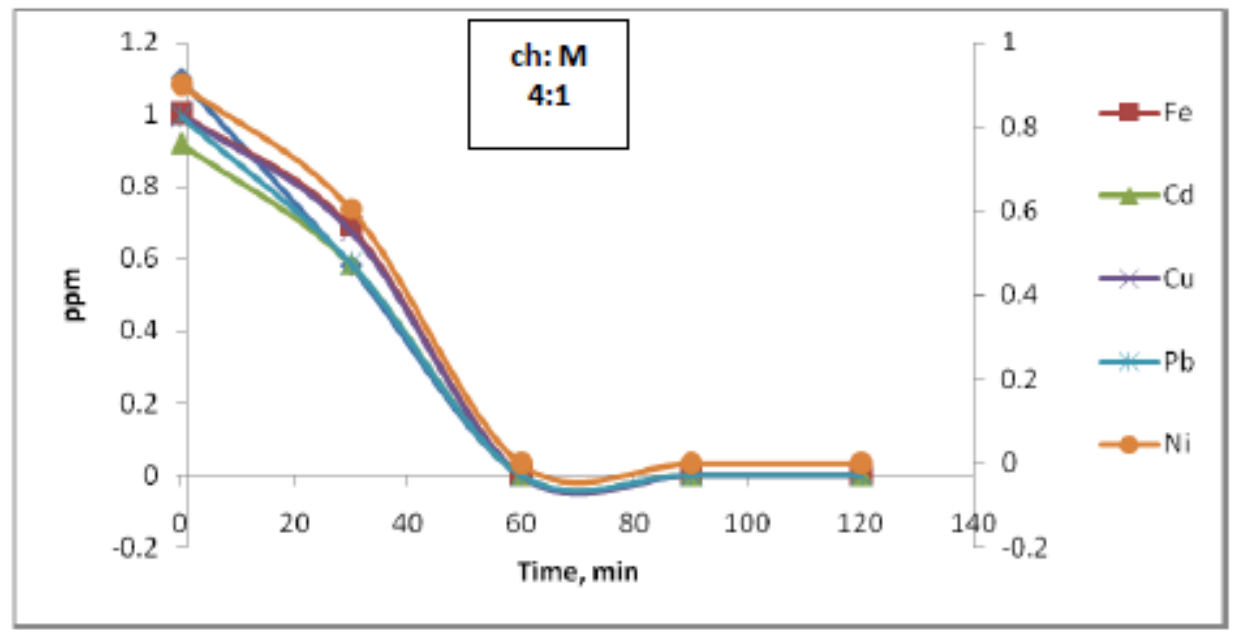

Figure 5:- Variation concentration of heavy metals at molar ratio (4ch:1M) against time

\subsection{DHS works as post-treatment at RHT $3 \mathrm{~h}$ in the absence of organic chelator:}

\section{Nitrogen balance and removal efficiency:}

Regarding nitrogen removal, it was observed that, the mode of nitrogen removal in the DHS reactor is nitrification followed by denitrification. The nitrifies residing in the retained wastewater of DHS reactor first convert ammonia to nitrite and nitrate which are then converted to gaseous nitrogen by denitrification in the anoxic zone of the sponge material. Variations in nitrite and nitrate concentrations are shown in Figures. 7 and 8 respectively. Nitrate and nitrite concentrations in the DHS effluent fluctuated between 0.2 and $0.4 \mathrm{mg} / \mathrm{l}$. Nitrification in DHS takes place in the lower portion of the reactor where the increase in the Nitrate and nitrite is due to nitrification by nitrobacteria. (Figures.10 and 11)

\section{Fecal coliform removal:}

Removal of pathogenic organisms is one of the main objectives of municipal wastewater treatment for developing countries as it signifies the risk factor for public health. Many countries like Egypt have stringent standards regarding the presence of pathogens in groundwater as they directly affect the health and sanitation conditions of the population in the present study, fecal coliform was chosen as an indicator for pathogenic organisms. It is well understood that, anaerobic reactors does not significantly contribute to the removal of coliforms. However, relatively good results were achieved using the DHS reactor. The geometric mean of fecal coliform count in the DHS reactor effluent was reduced by $99 \%$. The relatively higher performance could be due to adsorption and bio-filtration of fecal coliform by curtain sponge packing in the sedimentation section of the DHS reactor. Furthermore, a substantial drop of fecal 
International Journal of Advances in Chemistry (IJAC) Vol. 4, No.1, February 2018

coliform counts has been reported in the final effluent with residual count of $25 \mathrm{MF} / 100 \mathrm{ml}$. These results indicated that, the DHS reactor is more effective for the removal of fecal coliform as compared to other aerobic systems[31].It was found that, reverse osmosis (RO) system treating groundwater achieved a reduction in fecal coliform count of $99.74 \%$. Also, one likely reason of the higher performance of DHS reactor could be the higher amount of reserved water and long SRT. The results show that the removal efficiency of fecal coliform removal efficiencies in DHS was $94 \%(25 \pm 5 \mathrm{CFU} / 100 \mathrm{ml})$ where sponge bulk volume were found to be the most important factors affecting entrapment of fecal coliform in DHS system treating. (Fig.12). Tables 1-4 show the results obtained using DHS system.

Table (1):- Performance results of DHS system in treating ground water at a total HRT of $3 \mathrm{~h}$ (January).

\begin{tabular}{|c|c|c|c|c|}
\hline \multirow{2}{*}{ S } & \multirow{2}{*}{ Parameter } & \multirow{2}{*}{ Unit } & \multicolumn{2}{|c|}{ Result } \\
\cline { 3 - 5 } & & & Raw 1 & Run 1 \\
\hline 1 & PH & Unit & 7.01 & 6.98 \\
\hline 2 & TDS & Ppm & 152 & 112 \\
\hline 3 & TOTAL HARDNESS & Ppm & 88 & 62 \\
\hline 4 & (CA) HARDNESS & Ppm & 52 & 42 \\
\hline 5 & (MG) HARDNESS & Ppm & 36 & 20 \\
\hline 6 & Nitrite $\left(\mathrm{NO}_{2}\right)$ & Ppm & 4 & 3.3 \\
\hline 7 & Nitrate $\left(\mathrm{NO}_{3}\right)$ & Ppm & 0.7 & 0.6 \\
\hline 8 & Fecal Coliform & CFU/100mL & 2 & nil \\
\hline
\end{tabular}

The results revealed that, the average removal values of TDS, Total Harddness, Ca Hardness, $\mathrm{Mg}$ Hardness, $\mathrm{NO}_{2}, \mathrm{NO}_{3}$ and Fecal Coliform are 27\%, 30\%, 20\%, 45\%,18.2\%,15\% and 100\% respectively.

Table (2):- Performance results of DHS system in treating ground water at a total HRT of $3 \mathrm{~h}$ (May).

\begin{tabular}{|c|c|c|c|c|}
\hline \multirow{2}{*}{ S } & \multirow{2}{*}{ Parameter } & \multirow{2}{*}{ Unit } & \multicolumn{2}{|c|}{ Result } \\
\cline { 3 - 5 } & & & Raw 2 & Run 2 \\
\hline 1 & & Unit & 7.2 & 6.93 \\
\hline 2 & PH & Ppm & 178 & 137 \\
\hline 3 & TOTAL HARDNESS & Ppm & 118 & 104 \\
\hline 4 & (CA) HARDNESS & Ppm & 82 & 72 \\
\hline 5 & (MG) HARDNESS & Ppm & 36 & 32 \\
\hline 6 & Nitrite $\left(\mathrm{NO}_{2}\right)$ & Ppm & 5 & 3.9 \\
\hline 7 & Nitrate $\left(\mathrm{NO}_{3}\right)$ & Ppm & 0.9 & 0.8 \\
\hline 8 & Fecal Coliform & CFU/100mL & nil & Nil \\
\hline
\end{tabular}

The results revealed that, the average removal values of TDS,Total Harddness, Ca Hardness, $\mathrm{Mg}$ Hardness, $\mathrm{NO}_{2}, \mathrm{NO}_{3}$ and Fecal Coliform are 24\%, 12\%, 13\%, 12.2\%,22.2\%, $12 \%$ and $100 \%$ respectively. 
International Journal of Advances in Chemistry (IJAC) Vol. 4, No.1, February 2018

Table (3):- Performance results of DHS system in treating ground water at a total HRT of $3 \mathrm{~h}$ (September).

\begin{tabular}{|c|c|c|c|c|}
\hline \multirow{2}{*}{ S } & Parameter & \multirow{2}{*}{ Unit } & \multicolumn{2}{|c|}{ Result } \\
\cline { 3 - 5 } & & & Raw 3 & Run 3 \\
\hline 1 & PH & Unit & 6.9 & 7 \\
\hline 2 & TDS & Ppm & 152 & 62 \\
\hline 3 & TOTAL HARDNESS & Ppm & 88 & 42 \\
\hline 4 & (CA) HARDNESS & Ppm & 52 & 20 \\
\hline 5 & (MG) HARDNESS & Ppm & 36 & 0.5 \\
\hline 6 & Nitrite $\left(\mathrm{NO}_{2}\right)$ & Ppm & 0.8 & 2 \\
\hline 7 & Nitrate $\left(\mathrm{NO}_{3}\right)$ & Ppm & 3 & 1 \\
\hline 8 & Fecal Coliform & CFU/100mL & 10 & \\
\hline
\end{tabular}

The results revealed that, the average removal values of TDS,Total Harddness, Ca Hardness, $\mathrm{Mg}$ Hardness, $\mathrm{NO}_{2}, \mathrm{NO}_{3}$ and Fecal Coliform are 27\%, 24.5\%, 19.3\%, 45\%, 37.5\%, 34\% and 90\% respectively.

Table (4):- Performance results of DHS system in treating ground water at a total HRT of $3 \mathrm{~h}$ (December).

\begin{tabular}{|c|c|c|c|c|}
\hline \multirow{2}{*}{ S } & Parameter & \multirow{2}{*}{ Unit } & \multicolumn{2}{|c|}{ Result } \\
\cline { 3 - 5 } & & & Raw 1 & Run 1 \\
\hline 1 & PH & Unit & 7.01 & 6.98 \\
\hline 2 & TDS & Ppm & 168 & 120 \\
\hline 3 & TOTAL HARDNESS & Ppm & 92 & 62 \\
\hline 4 & (CA) HARDNESS & Ppm & 53 & 40 \\
\hline 5 & (MG) HARDNESS & Ppm & 39 & 22 \\
\hline 6 & Nitrite $\left(\mathrm{NO}_{2}\right)$ & Ppm & 3.1 & 2.9 \\
\hline 7 & Nitrate $\left(\mathrm{NO}_{3}\right)$ & Ppm & 0.9 & 0.7 \\
\hline 8 & Fecal Coliform & CFU/100mL & 1 & nil \\
\hline
\end{tabular}

The results revealed that, the average removal values of TDS,Total Harddness, Ca Hardness, $\mathrm{Mg}$ Hardness, $\mathrm{NO}_{2}, \mathrm{NO}_{3}$ and Fecal Coliform are 49\%, 33\%, 25\%, 43.6\%, 16.5\%, $23 \%$ and 100\% respectively.

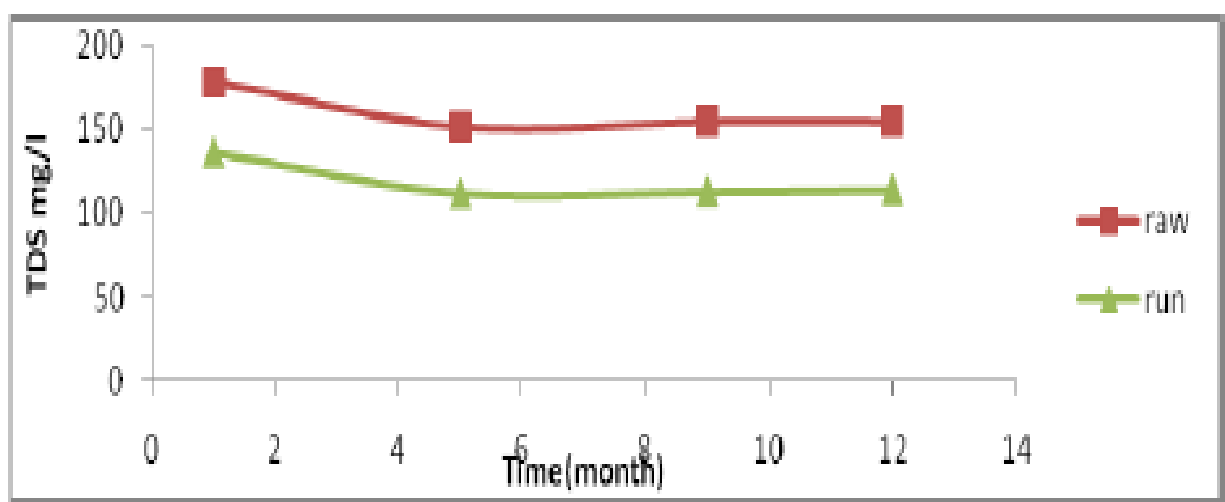

Fig.6:- Variation in TDS along DHS treatment system 
International Journal of Advances in Chemistry (IJAC) Vol. 4, No.1, February 2018

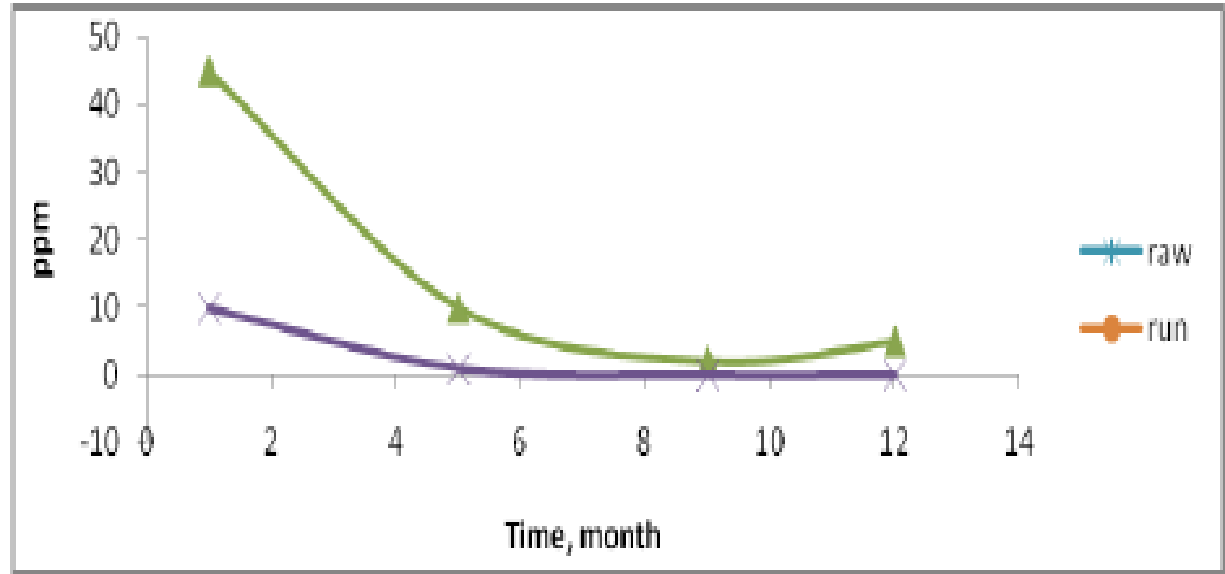

Fig.7:- Variation in nitrite $\left(\mathrm{NO}_{2}\right)$ along DHS treatment system

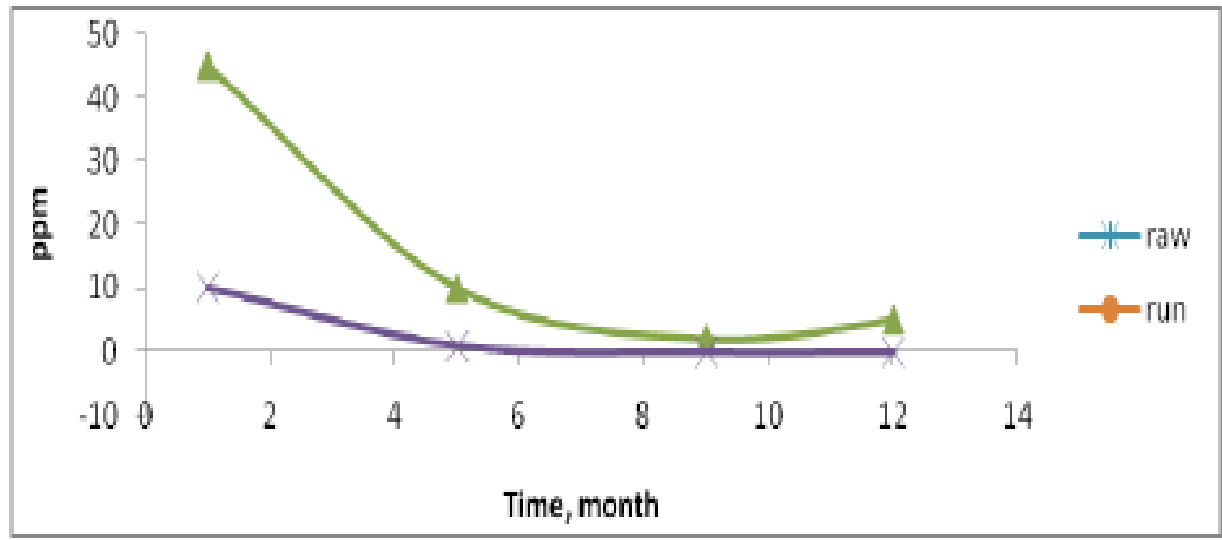

Fig.8:- Variation in nitrate $\left(\mathrm{NO}_{3}\right)$ along DHS treatment system

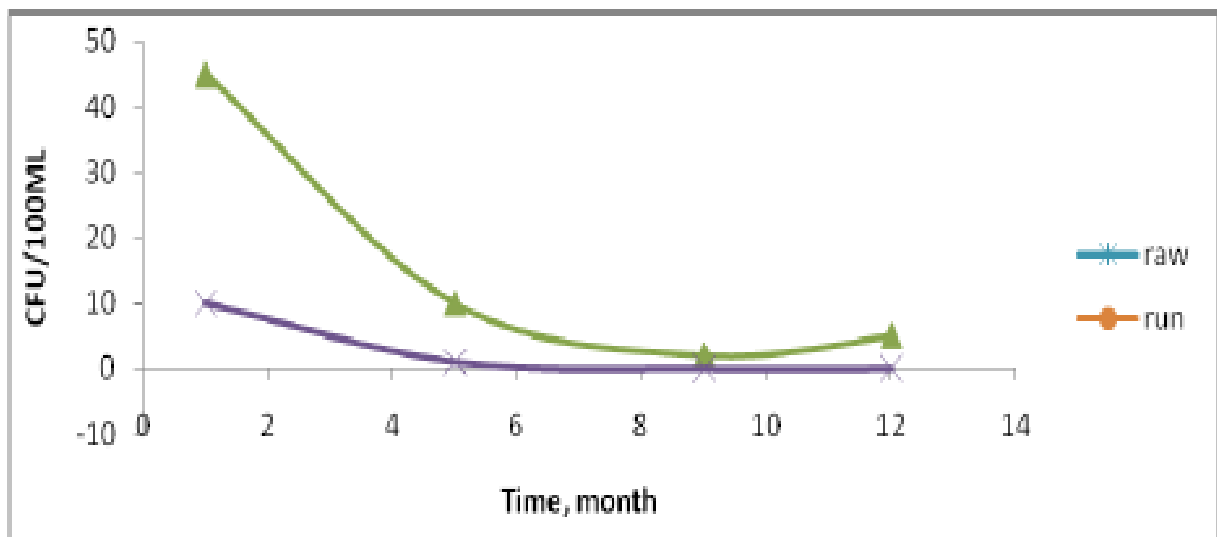

Fig.9:- Variation in Fecal Coliform along DHS treatment system 
International Journal of Advances in Chemistry (IJAC) Vol. 4, No.1, February 2018

\subsection{DHS work as post-treatment at RHT $3 \mathrm{~h}$ in presence of chelator(at dose $0.2 \mathrm{gL}^{-1}$ from the chelator)}

In the presence of $0.2 \mathrm{~g} / \mathrm{L}$ of the chelator, the results revealed that, the average removal values of TDS, Total Hardness, Ca Hardness, $\mathrm{Mg}$ Hardness, $\mathrm{NO}_{2}, \mathrm{NO}_{3}$ and Fecal Coliform are 48\%, 55\%, $39 \%, 78 \%, 30.2 \%$ and $47 \%$ respectively.

Table (5):- Performance results of DHS system in treating ground water at a total HRT of $3 \mathrm{~h}$ (at dose $0.2 \mathrm{gL}^{-1}$ from the chelator).

\begin{tabular}{|c|c|c|c|c|c|}
\hline \multirow{2}{*}{ S } & Parameter & \multirow{2}{*}{ Unit } & \multicolumn{2}{|c|}{ Result } & \multirow{2}{*}{ Efficiency } \\
\cline { 4 - 5 } & & & Raw & Run & \\
\hline 1 & PH & Unit & 7.01 & 7 & \\
\hline 2 & TDS & ppm & 152 & 80 & $48 \%$ \\
\hline 3 & TOTAL HARDNESS & ppm & 88 & 40 & $55 \%$ \\
\hline 4 & $(\mathrm{CA}) \mathrm{HARDNESS}$ & $\mathrm{ppm}$ & 52 & 32 & $39 \%$ \\
\hline 5 & $(\mathrm{MG}) \mathrm{HARDNESS}$ & $\mathrm{ppm}$ & 36 & 8 & $78 \%$ \\
\hline 6 & Nitrite $\left(\mathrm{NO}_{2}\right)$ & $\mathrm{ppm}$ & 1.2 & 0.85 & $30.2 \%$ \\
\hline 7 & Nitrate $\left(\mathrm{NO}_{3}\right)$ & $\mathrm{ppm}$ & 1.13 & 0.60 & $47 \%$ \\
\hline
\end{tabular}

Table (6): Performance results of heavy metals and fecal coliform removal at $0.2 \mathrm{~g} / \mathrm{l}$ of chelator.

\begin{tabular}{|c|l|c|c|c|c|}
\hline \multicolumn{2}{|c|}{ Parameters } & Unit & Raw & Run & Efficiency \\
\hline \multirow{4}{*}{ Heavy Metals } & $\mathrm{Cd}$ & $\mathrm{mgL}^{-1}$ & 0.0061 & Nil & $100 \%$ \\
\cline { 2 - 6 } & $\mathrm{Cu}$ & $\mathrm{mgL}^{-1}$ & 0.0023 & Nil & $100 \%$ \\
\cline { 2 - 6 } & $\mathrm{Fe}$ & $\mathrm{mgL}^{-1}$ & 0.4 & 0.01 & $97.5 \%$ \\
\cline { 2 - 6 } & $\mathrm{Mn}$ & $\mathrm{mgL}^{-1}$ & 0.3 & 0.001 & $99.7 \%$ \\
\cline { 2 - 6 } & $\mathrm{Zn}$ & $\mathrm{mgL}^{-1}$ & 0.012 & Nil & $100 \%$ \\
\hline \multicolumn{2}{|c|}{ Fecal Coliform } & unit/100ml & 50 & 10 & $80 \%$ \\
\hline
\end{tabular}

\section{Heavy metals removal efficiency:}

The results show that, the residual values of heavy metals are $\mathrm{Cd}$ when treated with chelator, the amount decreases from 0.0063 to $0.0 \mathrm{mgL}^{-1}$ (100\%), $\mathrm{Cu}$ decreases from 0.0023 to $0.0 \mathrm{mgL}^{-1}$ (100\%), Fe decreases from 0.4 to $0.0 .01 \mathrm{mgL}^{-1}$ (97.5\%), Mn decreases from 0.3 to $0.001 \mathrm{mgL}^{-1}$ (99.7\%), Zn decreases from 0.012 to $0.0 \mathrm{mgL}^{-1}(100 \%)$. Particles of heavy metals should be absorbed and captured in the surface of the chelator surface area. Particles to be digested it should be captured first and the digestion and the biodegradation processes will be then occurred in the land. Available data indicates good performance of the chelator regard to heavy metals removal efficiency.

\section{Bacterial treatment:}

The results show that, the residual values of fecal coliform when treated with chelator, the amount decreases from 50 to $10 \mathrm{CFU} / 100 \mathrm{ml}(80 \%)$. 
International Journal of Advances in Chemistry (IJAC) Vol. 4, No.1, February 2018

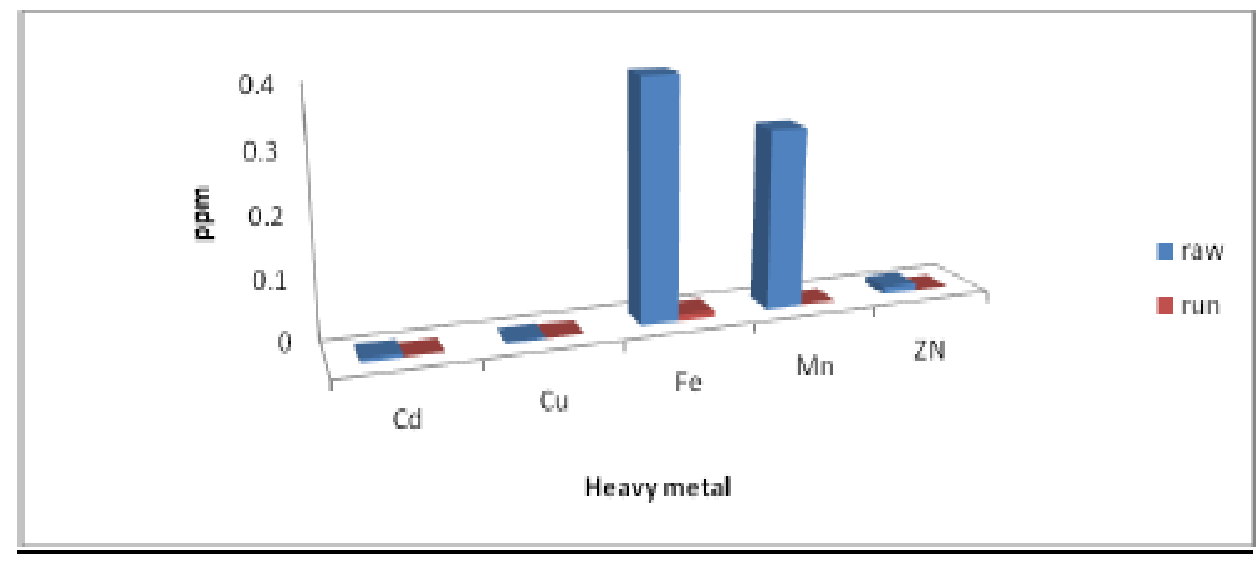

Fig. (10): Variation in heavy metals concentrations along raw and treated groundwater.

\subsection{DHS work as post-treatment at RHT $3 \mathrm{~h}$ in presence of chelator $\left(0.5 \mathrm{gL}^{-1}\right.$ from the chelator).}

Table (7): Performance results of heavy metals removal at $0.5 \mathrm{~g} / \mathrm{l}$ of chelator.

\begin{tabular}{|c|c|c|c|c|c|}
\hline S & \multirow{2}{*}{ Parameter } & \multirow{2}{*}{ Unit } & \multicolumn{2}{|c|}{ Result } & \multirow{2}{*}{ Efficiency } \\
\cline { 4 - 5 } & & & Raw & Run & \\
\hline 1 & PH & Unit & 6.93 & 7.01 & \\
\hline 2 & TDS & ppm & 208 & 158 & $75 \%$ \\
\hline 3 & TOTAL HARDNESS & ppm & 111 & 55.2 & $78 \%$ \\
\hline 4 & (CA) HARDNESS & ppm & 58.6 & 29.3 & $68 \%$ \\
\hline 5 & (MG) HARDNESS & ppm & 56.8 & 25.9 & $66 \%$ \\
\hline 6 & Nitrite $\left(\mathrm{NO}_{2}\right)$ & ppm & 1 & 0.2 & $62 \%$ \\
\hline 7 & Nitrate $\left(\mathrm{NO}_{3}\right)$ & ppm & 13 & 2 & $72 \%$ \\
\hline
\end{tabular}

In the presence of $0.5 \mathrm{~g} / \mathrm{L}$ of the chelator, the results revealed that, the average removal values of TDS, total hardness, Nitrite and Nitrate are $75 \%, 78 \%, 62 \%$ and $72 \%$ respectively.

Table (8): Performance results of heavy metals removal at $0.5 \mathrm{~g} / \mathrm{l}$ of the chelator.

\begin{tabular}{|c|l|c|c|c|c|}
\hline \multicolumn{2}{|c|}{ Parameters } & Unit & Raw & Run & Efficiency \\
\hline \multirow{4}{*}{ Heavy Metals } & $\mathrm{Cd}$ & $\mathrm{mgL}^{-1}$ & 0.0061 & 0 & $100 \%$ \\
\cline { 2 - 6 } & $\mathrm{Cu}$ & $\mathrm{mgL}^{-1}$ & 0.0023 & 0 & $100 \%$ \\
\cline { 2 - 6 } & $\mathrm{Fe}$ & $\mathrm{mgL}^{-1}$ & 0.4 & 0 & $100 \%$ \\
\cline { 2 - 6 } & $\mathrm{Co}$ & $\mathrm{mgL}^{-1}$ & 0.3 & 0 & $100 \%$ \\
\cline { 2 - 6 } & $\mathrm{Zn}$ & $\mathrm{mgL}^{-1}$ & 0.012 & 0 & $100 \%$ \\
\hline \multicolumn{2}{|c|}{ Fecal Coliform } & $\mathrm{CFU} / 100 \mathrm{ml}$ & 50 & 0 & $100 \%$ \\
\hline
\end{tabular}

\section{Heavy metals removal efficiency:}

The results shows that the residual values of heavy metals are $\mathrm{Cd}$ when treated with chelator, the amount decreases from 0.0063 to $0.0 \mathrm{mgL}^{-1}$ (100\%), $\mathrm{Cu}$ decreases from 0.0023 to $0.0 \mathrm{mgL}^{-1}$ 
International Journal of Advances in Chemistry (IJAC) Vol. 4, No.1, February 2018

(100\%), Fe decreases from 0.4 to $0.0 \mathrm{mgL}^{-1}$ (100\%), Mn decreases from 0.3 to $0.0 \mathrm{mgL}^{-1}$ (100\%), $\mathrm{Zn}$ decreases from 0.012 to $0.0 \mathrm{mgL}^{-1}(100 \%)$.

\section{Bacterial treatment:}

The results show that the residual values of fecal coliform when treated with chelators, the amount decreases from 50 to $0 \mathrm{MF} / 100 \mathrm{ml}(100 \%)$.

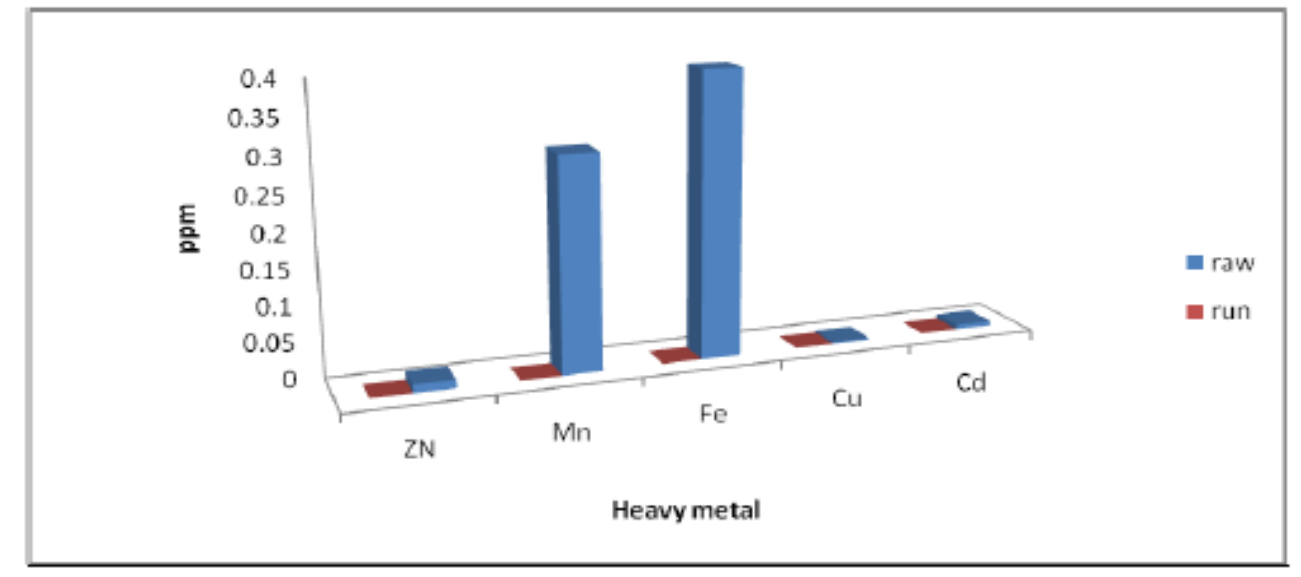

Fig. (11): Variation in heavy metals concentrations along raw and treated groundwater.

\section{CONCLUSION}

Improve the quality of treated water with low cost. It is safe to be used for human drinking water. In this study, DHS was used for direct treatment of ground water in the presence of chelator in removal of $\mathrm{NO}_{2}, \mathrm{NO}_{3}$ and fecal coliform at fixed hydraulic retention time ( $3 \mathrm{~h}$ and $6 \mathrm{~h}$ ) based on the sponge volume. Also, this study showed tremendous decrease in $\mathrm{NO}_{2}, \mathrm{NO}_{3}$ and fecal coliform (up to $99 \%$ ). This study showed that the smaller the sponge sizes of the DHS reactor, the better the removal efficiency. So we can use DHS in small village that cannot be serviced by city water network as secondary treatment for ground water.

\section{REFERENCES}

[1] Tema, W. Introducing water education through non-formal channels. in Water Education in African Cities; Report of an Expert Group Meeting, Johannesburg. 2001.

[2] Supply, W., S.C. Council, and UNICEF, Global water supply and sanitation assessment 2000 report: summary of the report, in Global water supply and sanitation assessment 2000 report: summary of the report. 2000.

[3] Metcalf, et al., Wastewater engineering: treatment and reuse. 2003: McGraw Hill.

[4] Droste, R.L., Theory and practice of water and wastewater treatment. 1997: John Wiley \& Sons Incorporated. 
International Journal of Advances in Chemistry (IJAC) Vol. 4, No.1, February 2018

[5] Kassab, G., et al., Sequential anaerobic-aerobic treatment for domestic wastewater-A review. Bioresource Technology, 2010. 101(10): p. 3299-3310.

[6] Ali, I. and H. Aboul-Enein, Instrumental methods in metal ions speciation: Chromatography, Capillary Electrophoresis and Electrochemistry. 2006, Taylor \& Francis Ltd., New York, USA.

[7] John, D.Z., Handbook of drinking water quality: Standards and controls. Vannostrand Reinhold, New York, 1990.

[8] Taheri, E., et al., Evaluation of the influence of conventional water coolers on drinking water quality. Iranian Journal of Health and Environment, 2010. 2(4): p. 268-275.

[9] Rahman, M.M., G. Owens, and R. Naidu, Arsenic levels in rice grain and assessment of daily dietary intake of arsenic from rice in arsenic-contaminated regions of Bangladesh-implications to groundwater irrigation. Environmental Geochemistry and Health, 2009. 31(1): p. 179-187.

[10] Network, E.s.W.I., EPA’s Watershed Information Network. 2004. p. 354-367.

[11] Letterman, R., American Water Works Association: Water Quality and Treatment. A Handbook of Community Water Supplies, 5th edn., McGraw-Hall, New York, 1999.

[12] Ali, I., H.Y. Aboul-Enein, and V.K. Gupta, Nanochromatography and nanocapillary electrophoresis: pharmaceutical and environmental analyses. 2009: John Wiley \& Sons.

[13] Duffus, J.H., " Heavy metals" a meaningless term?(IUPAC Technical Report). Pure and applied chemistry, 2002. 74(5): p. 793-807.

[14] Vettorazzi, G., International regulatory aspects for pesticide chemicals. Vol. I. Toxicity profiles. 1979: CRC Press Inc.

[15] Zhu, C., et al., Removal of cadmium from aqueous solutions by adsorption on granular red mud (GRM). Separation and Purification Technology, 2007. 57(1): p. 161-169.

[16] Ali, I., New generation adsorbents for water treatment. Chemical reviews, 2012. 112(10): p. 50735091.

[17] Pérez-Marín, A., et al., Removal of cadmium from aqueous solutions by adsorption onto orange waste. Journal of hazardous materials, 2007. 139(1): p. 122-131.

[18] Zhang, F.-S., J.O. Nriagu, and H. Itoh, Mercury removal from water using activated carbons derived from organic sewage sludge. Water research, 2005. 39(2): p. 389-395.

[19] Bayramoğlu, G. and M.Y. Arica, Kinetics of mercury ions removal from synthetic aqueous solutions using by novel magnetic p (GMA-MMA-EGDMA) beads. Journal of hazardous materials, 2007. 144(1): p. 449-457.

[20] Onodera, T., et al., Development of a sixth-generation down-flow hanging sponge (DHS) reactor using rigid sponge media for post-treatment of UASB treating municipal sewage. Bioresource technology, 2014. 152: p. 93-100.

[21] Sigel, H., Metal Ions in Biological Systems: Volume 20: Concepts on Metal Ion Toxicity. Vol. 20. 1986: CRC Press. 
International Journal of Advances in Chemistry (IJAC) Vol. 4, No.1, February 2018

[22] Sharma, Y., et al., Nano-adsorbents for the removal of metallic pollutants from water and wastewater. Environmental Technology, 2009. 30(6): p. 583-609.

[23] Vatistas, N. and M. Bartolozzi, Zinc contamination in the cathodic material of exhausted alkaline manganese dioxide batteries. Journal of power sources, 1999. 79(2): p. 199-204.

[24] Weng, C.-H. and C. Huang, Adsorption characteristics of Zn (II) from dilute aqueous solution by fly ash. Colloids and Surfaces A: Physicochemical and Engineering Aspects, 2004. 247(1): p. 137-143.

[25] Ören, A.H. and A. Kaya, Factors affecting adsorption characteristics of Zn 2+ on two natural zeolites. Journal of Hazardous Materials, 2006. 131(1): p. 59-65.

[26] Kross, B., A. Ayebo, and L. Fuortes, Methemoglobinemia: nitrate toxicity in rural America. American family physician, 1992. 46(1): p. 183-188.

[27] Organization, W.H., Guidelines for drinking-water quality. Vol. 1. 2004: World Health Organization.

[28] Barceló, D., Emerging organic pollutants in waste waters and sludge. Vol. 5. 2005: Springer Science $\&$ Business Media.

[29] Meyers, R.A., Encyclopedia of environmental pollution and cleanup. 1999.

[30] Organization, W.H., Persistent organic pollutants: impact on child health. 2010.

[31] Dyson, T., Population and food: global trends and future prospects. 1996: Routledge 